\title{
Hubungan Kecemasan Terhadap Produksi ASI Ibu Dengan Persalinan Seksio Sesaria
}

\author{
Ika Wulansari, Ns, M. Kep., Sp. Kep. Mat ${ }^{(1)}$, Ridha Hafid, S.ST. M.Kes ${ }^{(2)}$, dr. Nanang \\ Roswita Paramata, M.Kes ${ }^{(3)}$, Erni Darmayanti, S.Kep. Ns ${ }^{(4)}$ \\ Departemen Keperawatan Maternitas, Program Studi Ilmu Keperawatan, \\ Universitas Negeri Gorontalo \\ Iwulansari18@gmail.com
}

\begin{abstract}
Abstrak
Menyusui merupakan salah satu cara yang paling efektif untuk memberikan nutrisi dan menjaga kesehatan bayi. Pemberian ASI eksklusif juga mampu mengurangi angka kesakitan dan kematian bayi namun saat ini pemberian ASI eksklusif masih rendah presentasinya, Produksi ASI yang tidak mencukupi kebutuhan bayi akan menyebabkan kegagalan pemberian ASI eksklusif. Salah satu faktor penyebab berkurangnya produksi ASI pada ibu postpartum adalah kecemasan. Penelitian ini bertujuan untuk mengetahui hubungan antara kecemasan terhadap produksi ASI ibu dengan persalinan seksio sesaria di Kota Gorontalo. Penelitian ini menggunakan desain penelitian deskriptif analitik dengan pendekatan cross-sectional, yang melibatkan 30 orang responden pasca operasi seksio sesaria di Kota Gorontalo. Hasil uji statistic chi-square menunjukkan bahwa ada hubungan antara kecemasan ibu postpartum terhadap produksi ASI dengan nilai $p$ value 0,000. Hasil ini membuktikan bahwa kecemasan merupakan salah satu faktor yang bisa mempengaruhi produksi ASI ibu menyusui.
\end{abstract}

Kata kunci:, Kecemasan, Produksi ASI, postpartum

\begin{abstract}
Breastfeeding is one of the most effective ways to provide nutrition and maintain a baby's health. Exclusive breastfeeding can also reduce morbidity and infant mortality, but currently exclusive breastfeeding is still low, inadequate milk production will cause the failure of exclusive breastfeeding. One factor that causes a decrease in milk production in postpartum mothers is anxiety. This study discusses the relationship between anxiety and the mother's milk production with cesarean delivery in Gorontalo City. This study uses a descriptive-analytic research design using cross-sectional, involving 30 respondents after caesarean surgery in Gorontalo City. Chi-square statistical test results show there is a relationship between postpartum maternal anxiety with breast milk production with a p-value of 0,000 . These results prove fact that anxiety is one of the factors that can affect the milk production.
\end{abstract}

Key words: Anxiety, milk production, postpartum

\section{Pendahuluan}

Menyusui merupakan salah satu cara yang paling efektif untuk memberikan nutrisi dan menjaga kesehatan bayi. ASI (Air susu ibu) sangat aman, bersih dan mengandung antibodi yang membantu mencegah berbagai macam penyakit yang biasa menyerang anak. World Helath Organization (WHO) dan United Nation

\section{children's Fund}

(UNICEF)

merekomendasikan inisiasi menyusui mulai pada jam pertama kelahiran dan menjadi ASI eksklusif jika di berikan pada enam bulan pertama kehidupan yang artinya hanya di berikan ASI tanpa makanan atau minuman lainnya termasuk air (WHO. 2020).

ASI bisa memberikan manfaat baik bagi bayi maupun bagi ibu. Manfaat yang bisa di 
peroleh dengan memberikan ASI pada bayi karena ASI mengandung zat-zat pelindung yang sangat penting bagi bayi baru lahir, diantaranya adalah nutrisi, vitamin, mineral, antibodi dan juga ASI mengandung enzim yang dapat mengoptimalkan pencernaan. Sementara manfaat ASI bagi ibu yang memberikan ASI antara lain adalah dapat menurunkan resiko terkena kanker, obesitas, diabetes, dan pengakit jantung (Family LarssonRosenquist Foundation. 2018)

Dengan pemberian ASI eksklusif angka kesakitan dan kematian bayi yang tinggi bisa di kurangi. ASI dapat menurunkan angka kematian bayi akibat infeksi sebesar 88\%. Selain itu menyusui juga berkontribusi terhadap penurunan resiko stunting, obesitas dan penyakit kronis dimasa yang akan datang (Rokom, 2017). Meskipun manfaat ASI yang sangat besar bagi ibu dan bayi namun presentasi pemberian ASI ekslusif di beberapa Negara masih rendah. Salah satunya adalah Amerika Serikat, dimana pada tahun 2014 presentasi pemberian ASI eksklusif pada bayi berusia di bawah 6 bulan berjumlah 26,43\% (WHO. 2019). Hasil ini tidak jauh berbeda dengan presentasi pemberian ASI eksklusif di Indonesia pada tahun 2015 hanya mencapai 55.7\%. Meskipun angka ini sudah lebih tinggi dari pada target renstra yang di targetkan yaitu 39\% akan tetapi masih membutuhkan perhatian agar terjadi peningkatan pemberian ASI eksklusif di seluruh wilayah Indonesia. Sementara untuk provinsi Gorontalo sendiri pemberian ASI eksklusif mencapai 46,8\% pada tahun 2015. Hasil ini masih jauh dari nilai rata-rata pemberian ASI eksklusif di Indonesia (Kemenkes, 2016)

Salah satu faktor yang menjadi penyebab rendahnya pemberian ASI eksklusif adanya masalah pada produksi ASI ibu setelah melahirkan. Beberapa ibu melahirkan mengeluhkan kurangnya produksi ASI sehingga membuat mereka beralih ke pemberian susu formula pada bayi. Kurangnya produksi ASI akan menyebabkan asupan nutrisi yang kurang pada bayi sehingga pertumbuhan dan pekerbangan anak bisa terganggu. Untuk menilai produksi ASI yang mencukupi kebutuhan bayi bisa di lihat melalui pertambahan berat badan bayi. Pada awal kehidupannya, seorang bayi pada minggu pertama kelahiran akan mengalami penurunan berat badan sebanyak $10 \%$ karena terjadi pengeluaran mekonium kemudian berat badan ini akan kembali ke berat badan semula dalam waktu tujuh hari. Kemudian setelahnya jika prouksi ASI mencukupi kebutuhan bayi maka pada hari ke 10 kelahiran bayi akan mengalami 
peningkatan Berat badan minimal sebanyak 300 gram. Jika dalam waktu 17 hari setelah lahir bayi tidak mengalami peningkatan berat badan maka bisa di katakana produksi ASI dari ibu masuk dalam kategori kurang (Wiji, 2013).

Produksi ASI yang kurang bisa di sebabkan oleh beberapa faktor diantaranya adalah asupan makan ibu, ketenangan jiwa dan fikiran, penggunaan alat kontrasepsi, perawatan payudara, anatomi buah dada, istirahat, isapan anak dan obat-obatan (Rayhana dan Sufriani. 2017). Selain itu faktor jenis persalinan juga bisa mempengaruhi produksi ASI seorang ibu. Ibu yang melalui persalinan seksio sesaria akan mengalami hambatan yang berbeda di bandingkan dengan ibu yang melahirkan secara normal. Hal ini karena saat persalinan jika ibu di berikan anastesi umum, maka setelah tindakan operasi ibu tidak sadar dan langsung bisa mengurus bayinya karena masih ada pengaruh anastesi. Selain itu nyeri pada daerah operasi juga menghambat proses menyusui (Sukarni dan Wahyu. 2013). Hal ini di dukung oleh penelitian Inrayati, Mustika, Nurwijayanti dan Latifah (2018) yang menyebutkan bahwa terdapat perbedaan produksi ASI yang signifikan antara ibu yang melakukan persalinan secara normal dan operasi seksio sesaria.
Selain faktor di atas, faktor psikologis juga bisa menyebabkan kurangnya produksi ASI, salah satunya adalah kecemasan. Kecemasan muncul sebagai reaksi terhadap kondisi yang dialami oleh ibu selama menjalani tahapan awal menghadapi bayi baru lahir. Ibu yang menyusui anaknya akan mengalami letdown reflex (LDR) atau disebut juga sebagai proses sekresi ASI setelah bayi menyusu. LDR juga dapat dipicu melalui faktor psikologis seperti mendengar tangisan bayi, berfikir tentang bayinya dan bisa juga saat berfikir tentang pemberian ASI sendiri, sebaliknya LDR ini dapat dihambat oleh kecemasan, ketakutan, perasaan tidak aman atau ketegangan. Faktor-faktor tersebut diperkirakan dapat meningkatkan kadar epinefrin dan norepinefrin yang selanjutnya akan menghambat transportasi oksitosin ke dalam payudara. Pada saat produksi ASI sudah terjadi dengan baik, pengosongan sakus alveoralis mammae yang teratur akan mempertahankan produksi tersebut (Farrer. 2001). Sehingga jika terjadi kecemasan maka pengosongan sakus alveorali akan terhambat sehingga akan mempengaruhi produksi ASI selanjutnya. Karena pengaruhnya yang bisa mengurangi produksi ASI dan menghambat pemberian ASI eksklusif, sehingga kecemasan 
merupakan faktor yang perlu di teliti lebih lanjut. Peneltian ini bertujuan untuk mengetahui hubungan kecemasan dengan produksi ASI ibu post partum dengan persalinan seksio sesaria.

\section{Metode Penelitian}

Penelitian ini merupakan penelitian deskriptif analisis dengan pendekatan cross-sectional. Penelitian ini melibatkan 30 orang responden yang merupakan ibu post partum hari ke 17 dengan persalinan seksio sesaria di Kota Gorontalo pada tahun 2017 yang memenuhi kriteria penelitian. Teknik sampling yang digunakan adalah probability sampling dengan metode consecutive sampling. Pengukuran kedua varabel menggunakan kuesioner.

Uji analisis bivariat di lakukan melalui pengujian chi square antara kecemasan dengan produksi ASI. Sebelum penelitian seluruh responden akan di jelaskan tentang mekanisme penelitian dan mengisi informed concent. Setelah di melakukan pengisian informed concent dan kuesioner seluruh responden diberikan penjelasan tentang produksi ASI.

\section{Hasil Penelitian}

Sebanyak 32 responden telah memenuhi kriteria penelitian, namun dua orang responden menolak sehingga total responden menjadi 30 orang yang terlibat sampai akhir penelitian. Karakteristik sampel sebagian besar adalah multigravida, dengan usia terbanyak berada antara 26-35 tahun dan tingkat pendidikan perguruan tinggi dan sebagian besar bekerja sebagai ibu rumah tangga

Tabel 1. Dsitribusi frekuensi dari karakteristik responden

\begin{tabular}{lcc}
\hline \multicolumn{1}{c}{ Karakteristik } & \multicolumn{2}{c}{$\mathrm{N}$} \\
& \multicolumn{2}{c}{$(\mathrm{n}=30)$} \\
\cline { 2 - 3 } & $\mathrm{N}$ & $\%$ \\
\hline Usia & 9 & 30 \\
$17-25$ & 16 & 53,3 \\
$26-35$ & 5 & 16,7 \\
$36-45$ & & \\
Pendidikan & 7 & 23,3 \\
SMP & 9 & 30 \\
SMA & 14 & 46,7 \\
$\quad$ Perguruan Tinggi & & \\
Pekerjaan & 17 & 56,6 \\
Ibu Rumah Tangga & 11 & 36,6 \\
$\quad$ PNS/Honor & 2 & 6,6 \\
$\quad$ Swasta & & \\
Lain-lain & & \\
Paritas & 13 & 43,3 \\
$\quad$ Primigravida & 17 & 56,7 \\
Multigravida & & \\
\hline
\end{tabular}

Penelitian ini menilai kecemasan pada hari ke 17 pasca persalinan seksio sesaria. Kecemasan responden menunjukkan sudah banyak yang mengalami penurunan.

Tabel 2. Distribusi frekuensi kecemasan pasca persalinan seksio sesaria

\begin{tabular}{ccc}
\hline Karakteristik & Frekuensi & Presentasi \\
\cline { 2 - 3 } & $\mathrm{N}$ & $\%$ \\
\hline Kecemasan & 24 & 80 \\
Tidak cemas & 6 & 6 \\
Cemas & &
\end{tabular}

Produksi ASI ibu pasca persalinan seksio sesaria pad ahari ke 17 pasca persalinan menunjukkan bahwa produksi 
ASI responden sebagian besar sudah menunjukkan produksi ASI yang cukup

Tabel 3. Produksi ASI ibu post partum dengan persalinan seksio sesaria

\begin{tabular}{clc}
\hline Karakteristik & Frekuensi & Presentasi \\
\hline & $\mathrm{N}$ & $\%$ \\
\hline Produksi ASI & \multicolumn{2}{c}{66,7} \\
Cukup & 20 & 33,3 \\
Kurang & 10 &
\end{tabular}

Analisis bivariat menunjukkan

bahwa terdapat hubungan antara

kecemasan dengan produksi ASI 17 hari

pasca persalinan dengan nilai $p$ value 0,000

Tabel 4. Analisis hubungan Kecemasan dengan produksi ASI

\begin{tabular}{cccccc}
\hline Kecemasan & \multicolumn{4}{c}{ Produksi ASI } & \multirow{2}{*}{$p$ value } \\
\cline { 2 - 4 } & \multicolumn{2}{c}{ Cukup } & \multicolumn{2}{c}{ Kurang } & \\
\cline { 2 - 5 } & $\mathrm{N}$ & $\%$ & $\mathrm{~N}$ & $\%$ & \\
\hline Tidak Cemas & 20 & 66,7 & 4 & 13,3 & 0,000 \\
Cemas & 0 & 0 & 6 & 20 & \\
Total & 20 & 66,7 & 10 & 33,3 & \\
\hline
\end{tabular}

\section{Pembahasan}

Hasil penelitian menunjukkan adanya hubungan antara kecemasan dengan produksi ASI ibu bersalin melalui seksio sesaria dengan nilai $p$ value 0,000 . Hasil ini berdasarkan fakta bahwa ibu yang mengalami kecemasan sebagian besar merupakan ibu primigravida yang tidak memiliki pengalaman sebelumnya. Ibu postpartum akan mengalami kecemasan yang disebabkan karena perasaan cemas dan khawatir karena baru saja memiliki anak (Sebastian. 2016). Nakić Radoš, Tadinac, dan Herman (2018) menyebutkan bahwa kecemasan terjadi pada $17 \%$ ibu setelah melahirkan, 20\% setelah 6 minggu persalinan. Hal ini menunjukkan perubahan kondisi setelah melahirkan dan hadirnya individu baru bisa menyebabkan kecemasan pada ibu postpartum.

Pada hasil penelitian di ketahui pula sebesar 20\% responden merasai kecemasan dan produksi ASI yang kurang. Stimuli dari bayi yang baru lahir akan membantu mengeluarkan ASI dari ibu atau yang biasa di sebut dengan LDR. Hipotalamus akan dengan mudah tersimuli melalui hisapan bayi, bau bayi yang di rasakan oleh ibu, tangisan bayi dan bahkan hanya dengan mengingat bayi maka akan menjadi pencetus saraf di otak untuk meningkatkan sintesis dan melepaskan oksitosin dari posterior pituitary ke dalam sirkulasi. Ketika sirkulasi tersebut mencapai jaringan payudara dan mempengaruhi sel myopitelial, proses ini menyebabkan kontraksi dan pelepasan ASI. Produksi dan pelepasan ASI dapat di pengaruhi oleh beberapa stimulus. LDR sendiri akan terhambat jika terjadi stress, kecemasan atau ketakutan yang menyebabkan terjadinya vasokontriksi melalui saraf simpatik yang menghambat akses oksitosin ke jaringan myopitelium payudara. Stres 
dan kecemasan juga dapat meningkatkan produksi dopamine di dalam tubuh sehingga bisa menurunkan produksi prolaktin yang akan mempengaruhi produksi ASI ( Filed, McCabe dan Schneiderman, 2013).

Lara-Cinisomo, McKenney, Di Florio, dan Meltzer-Brody (2017) menyebutkan dalam penelitiannya bahwa kecemasan berhubungan dengan periode menyusui seorang ibu. Penelitian ini menyebutkan kecemasan membuat banyak ibu memutuskan untuk berhenti menyusui pada saat bayi berusia dua bulan karena merasa bayinya kurang puas dengan ASI yang di berikan. Penelitian lain yang dilakukan oleh Septianingrum, Hatmanti, Fitriasari (2020) juga menyebutkan bahwa terdapat hubungan antara kecemasan dengan produksi ASI. semakin parah tingkat kecemasan seseorang makan produksi ASI nya juga akan semakin terganggu. Kecemasan yang di hadapi ibu secara tidak langsung akan berdampak pada perubahan produksi ASI ibu itu sendiri sehingga bisa mengganggu pemberian ASI eksklusif pada bayi baru lahir.

Hasil penelitian juga menunjukkan bahwa beberapa ibu tidak mengalami produksi ASI yang kurang pada hari ke 17, hal ini dibisa disebabkan karena sebagian besar responden memiliki tingkat pendidikan yang tinggi. Pendidikan yang tinggi menyebabkan seseorang lebih mudah memahami informasi yang di peroleh baik dari tenaga kesehatan, keluarga maupun dari sumber lainnya sehingga berpengaruh pada psikologis reponden yang lebih siap dalam mengahadapi situasi yang ada, salah satunya saat mengalami kecemasan. Hal ini di dukung oleh penelitian yang dilakukan Pramudianti, Raden dan Suryaningsih (2017) yang menyebutkan bahwa tingkat pendidikan akan mempengaruhi sepf efficacy periode awal nifas pada ibu pasca section sesaria. Tingkat pendidikan akan menentukan pola fikir dan wawasan seseorang. Tingkat pendidikan yang tinggi akan membantu seseorang untuk mengolah informasi dan pengetahuan yang diterima. Pengetahuan akan membantu ibu dalam merubah perilaku dan menjadi modal dasar melakukan pengasuhan bayi yang baru dilahirkan.

\section{Simpulan}

Masa postpartum merupakan masa dimana ibu merasakan cemas karena perubahan yang terjadi dengan kehadiran bayi. Rasa khawatir, cemas dan stress yang di rasakan pada masa postpartum dapat mempengaruhi produksi ASI pada ibu sehingga bisa menyebabkan kegagalan pemberian ASI eksklusif. Ibu primipara 
merupakan ibu yang rentan terhadap

kejadian ansietas karena belum

berpengalaman memiliki bayi sebelumnya.

\section{Daftar Pustaka}

Farrer, H. (2001). Keperawatan maternitas.

EGC. Jakarta.

Family Larsson-Rosenquist Foundation. (2018). Breastfeeding and Breast Milk - From Biochemistry to Impact: A Multidisciplinary Introduction. New York. Georg Thieme Verlag.

Field. T. M., McCabe, P. M., Schneiderman, N. (2013). Stress and coping across development. New Jersey. Lawrence Erlbaum Assosiate, Inc. Publisher.

Indrayati, N., Mustika, A., Nurwijayanti., Latifah. E. M. (2018). Perbedaan produksi ASI pada ibu dengan persalinan normal dan seksio sesaria. Community of Publishing in Nursing. 6:2. ISSN: 2303-1298.

Kementrian kesehatan Republik Indonesia. (2016). Profil Kesehatan Indonesia Tahun 2015. Jakarta. Kementrian Kesehatan. ISBN 978-602-416065-4.

Lara-Cinisomo, S., McKenney, K., Di Florio, A., \& Meltzer-Brody, S. (2017). Associations Between Postpartum Depression, Breastfeeding, and Oxytocin Levels in Latina Mothers. Breastfeeding medicine : the official journal of the Academy of Breastfeeding
Medicine, 12(7), 436-442. https://doi.org/10.1089/bfm.2016.0 213

Nakić Radoš, S., Tadinac, M., \& Herman, R. (2018). Anxiety During Pregnancy and Postpartum: Course, Predictors and Comorbidity with Postpartum Depression. Acta clinica Croatica, 57(1), 39-51. https://doi.org/10.20471/acc.2017.5 6.04 .05

Pramudianti, D. C., Raden, A., Suryaningsih, E. K. (2017). Hubungan tingkat pendidikan formal dengan parenting selfefficacy periode awal nifas pada ibu pasca sectio caesarea. Jurnal kebidanan dan keperawatan. 13(1):34-41. DOI: 10.31101/jkk.194

Rayhana., Sufriani.(2017). Faktor-faktor yang mempengaruhi produksi ASI dengan Kecukupan ASI. Universitas Syiah Kuala Banda Aceh.

Rokom. Redaksi sehat negeriku. (2017). Menyusui dapat menurunkan angka kematian bayi. Kementrian Kesehatan Republik Indonesia. Diakses tangal 25 Juli 2020. http://sehatnegeriku.kemkes.go.id/b aca/rilismedia/20170809/0122144/menyus ui-dapat-menurunkan-angkakematian-bayi/

Sebastian L. (2016). Overcome postpartum depression and anxiety. Third edition. Nebraska.

Addicus Books, Inc.

Septianingrum, Y., Hatmanti, N. M., Fitriasari, A. (2020). Corelation 
between anxiety and breast milk production among breastfeeding mothers in public centre of Jagir, Surabaya. Nurse and health jurnal keperawatan. 9(1):50. DOI: 10.36720/nhjk.v9i1.151

Sukarni I., Wahyu. (2013). Buku ajar keperawatan maternitas. Nuha Medika. Yogyakarta.

Wiji, R. N. (2013). ASI dan panduan ibu menyusui, Yogyakarta . Nuha Medika.

World Health Organization. (2019). Infant exclusively breastfed fot the first six months of life. https://www.who.int/data/gho/data/ indicators/indicatordetails/GHO/infants-exclusivelybreastfed-for-the-first-six-monthsof-life-(-) diakses tanggal 26 Juli 2020.

World Health Organization. (2019). Breastfeeding. https://www.who.int/healthtopics/breastfeeding\#tab=tab_1. Diakses tanggal 26 Juli 2020. 